UNRAM Law Review is licensed under a Creative Commons Attribution 4.0 International License, which permits unrestricted use, distribution, and reproduction in any medium, provided the original work is properly cited. p-ISSN: 2548-9267 | e-ISSN : 2549-2365, Open Access at : http://unramlawreview.unram.ac.id/index.php/ulr

Volume 5 Nomor 1 April 2021

\title{
Analysis on Perpetrator of Klithih in Special Region of Yogyakarta
}

\author{
Endro Prasetyandoko \\ Kampus Terpadu UMY \\ Email: endro_prast21@gmail.com \\ Yeni Widowaty \\ Kampus Terpadu UMY \\ Email: yenywidowaty@umy.ac.id
}

\begin{abstract}
This crime often occurred and can directly be witnessed and committed publicly of Yogyakarta, this type of crime known as Klithih. Crimes committed by the offender emerge general reaction as this act may disturb public. It is not only harm a single victim but also multiple. This crime majorly offended by secondary senior high school teens. Aims of this research related to criminology study on Klithih offender in special region of Yogyakarta are to find out causing factors as well as to find out countermeasure efforts of the authorities on such a crime and enforcement concept on the crime in Yogyakarta. This research applied juridical-empirical legal research method namely applied procedure to overcome problems by researching secondary prior to analysing primary data that collecting from field research. The primary data collected from interviews with informants, meanwhile secondary data are collected from documentation, books, literatures and archives that related with research object. Data analysis is applying qualitative method that analysing normative (juridical) aspects under a descriptive-analysis manner. Research result indicates that (1) causing factors of Klithih crime in the special region of Yogyakarta are including revenge, circumstances, alcohol and the lack of education;(2) efforts taken by police to overcome Klithih crime in the special region of Yogyakarta namely penal and non-penal acts.
\end{abstract}

Keywords: Crime; Klithih Offenders; Special Region of Yogyakarta

\section{INTRODUCTION}

The type of crime that casually occurred and openly exposed in the Yogyakarta society called Klithih. Offenders of this crime gain ordinary reaction, even though it brought disturbing effect for community members. It is not only harm a single individual but multiple. Offenders are mainly students of junior or senior high school.

Klithih has become a tradition for generations that pass from senior school students to their juniors. In conducting the crime, offender targeted someone or a group of people in the street, usually students of other school that they conflicted with or those who wearing certain uniform. Reasons behind this act are revenge and also to expose offenders' group identities as these groups compete each other. It is not offended individually but in group attacking victim spontaneously or targeted before. 
Number of such a street crime can be seen from data of Yogyakarta police department (Polda DIY) as shown it table below :

Tabel 1

Data of Klithih acts in Yogyakarta police department

\begin{tabular}{|l|l|c|c|c|}
\hline \multirow{2}{*}{ No Area } & \multicolumn{3}{|c|}{ Year } \\
\cline { 3 - 5 } & & $\mathbf{2 0 1 7}$ & $\mathbf{2 0 1 8}$ & $\mathbf{2 0 1 9}$ \\
\hline 1 & Polresta Yogyakarta & 12 & 7 & 7 \\
\hline 2 & PolresSleman & 19 & 22 & 15 \\
\hline 3 & Polres Bantul & 13 & 13 & 8 \\
\hline 4 & PolresKulonProgo & - & 1 & 4 \\
\hline 5 & PolresGunungkidul & 6 & 7 & 5 \\
\hline & Jumlah & $\mathbf{5 0}$ & $\mathbf{5 0}$ & $\mathbf{3 9}$ \\
\hline
\end{tabular}

Source: Polda DIY

According to the table, Klithih is mainly conducted by underage children or teenagers. It can be seen that the number of crime fluctuated in the year of 2017 and 2018 but decreased in 2019.

Klithih meant to hurt it victims and sometimes even killed them using several tools such as knife or samurai. There is no victim specialization whether it has to be female, male or even older people as offender pick it randomly. This phenomenon leads to negative image of the city that usually known as the city of students.

This crime is worrying as nearly every month there are always victims. Therefore, citizens initiate night patrol to anticipate the repetitive crime. Police officers also conducted city patrol in order to minimize the crime.

As a teenager crime, it required adventive and preventive solution to solve it. It also required participation of all community members including parents, teachers/ educators, government including police officers. Klithih as a crime in Yogyakarta has entered disturbing level which in contract with the image of the city as education and cultural centre.

Based on the above background, several problems are formulated as follows:

1. What are the causing factors of Klithih crime in the the special region of Yogyakarta?

2. What are macro criminology actions can be taken to prevent and eradicate Klithih crime in the special region of Yogyakarta? 


\section{ANALYSIS AND DISCUSSION}

\section{Causing factors of Klithih crime in the special region of Yogyakarta}

Leading factor that encourage the act of Klithih is revenge as the offenders once a victim that makes them want to pay back. Personal character as well as family and friends circumstance leads to aggressiveness of the offenders. In other words, family and friends around children influence them to committed Klithih.

Based on interview with AKP Ngadi, SH the head of crime unit (KASATRESKRIM) in Bantul regency Police department "the caught offender has been proceed and sentenced to prison, some of them only being trained as they did not bring armor in the night convoy"

Further, according toAKP Deni Irwansyah KASATRESKRIM Sleman, The actual number of Klithih offender potentially more that exposed in data as many of the offenders released since they only gathered in night time without involving weapons or alcohol. Whereas such a night gathering often triggering the act of Klithih. Besides, many offenders escape or released due to the lack of evident or witness.

Basically, there is combination of factors leads to the occurrence of this crime. One of the main factors is the lack of affection and care from parents due to long working hours. AKP Rico Sanjaya, KASATRESKRIM Yogyakarta police department added that another factor is individual character. According to the above causing factors of Klithih crime in the special region of Yogyakarta, I will undertake criminology approach to describe them further.

\section{Revenge factor}

Feeling of angry is a kind innerinsistence to be released. As it continuously insisted in mind, once there is an opportunity, revenge will take be occurred. In an interview with AKP Ngadi, SH, KANITRESKRIM of Bantul regency police department described that"there is one case ofKlithih in Bantul where the victim, one of senior high school student was dead due to revenge act of his senior. The act resulted from conflict among school students which has been take place for many years.

The revenge can also triggered by one experience as victim in the past. Jogja tribunnews. com published that a teen initialled MIH (19) alias Gendut resident of Sewon, Bantul was arrested by police officer due to stabbing two other students. MIH committed it because wanted to revenge as he once a Klithih victim. He admitted brought knife to guard of in order to avoid being victimize again, after stabbing his victim, he thrown away the knife. That night when got caught Gendut admitted that he was driven by revenge to Klithih offender who attacked him 
when committed the crime. He noted that he was attacked at Niten market on last Saturday night, his helmet and back got ripped by sword. ${ }^{1}$

In general, the desire to revenge is strongly related someone's personal character. In other words, unconsciously if someone has a vengeful character, once he/she felt hurt, the desire of revenge will unconsciously emerge. It can appear at any circumstances including family. Therefore, intense communication might be the most suitable solution for this issue.

\section{Factor of crime-supportive environment}

The factor of less parent supervised environment hold substantial role in the existence of such a crime. AKP Rico Sanjaya, KSATRESKRIM of Yogyakarta stated that, the lack of parent supervision leads children uncontrolled behavior that enables the committed the crime. It can be caused by parents too busy to work that they can allow adequate time to pay attention to their children. Hence, they could only provide material needs. Another trigger is divorced parents or living with single mother, as the mother too busy working, children would lack of affection.

It is human basic need to be admitted, cared, complemented and loved by surroundings especially parents and family. Naturally, someone has strong connection with parents and family. Once the need unfulfilled by home, it will searched elsewhere. The most common place to search for it is within friends circle as children. Unfortunately, for the broken home children it often lead to negative acts.

A research indicates that Klithih behavior influenced by growing environment of the offender namely family, friends and community. In line with that Bandura in Sarwono and Meinarno suggested that aggressive behavior is a result of social learning process through observation of a community. An individual becomes aggressive as a respond to the social environment. Family is the most important aspect of someone's ideal growth. Teenagers that grow in troubled family and less parent affection potentially become aggressive. ${ }^{2} \backslash$

To be specific, one of Klithih triggering factors is the lack of family affection and education. Parents are children first educators. Based on data provided by study centre of residential and policy (PSKK), UGM, most of Klithih offenders come from low economic status families, some from broken home families. A survey conducted by PSKK UGM indicates that lack of parents role in education become the top factor of students violent. Based on the survey, parents are less supervised their children especially in the using of gadget ${ }^{3}$. It resulted the lack

\footnotetext{
${ }^{1}$ Dendam Terkena Klitih, Pemuda Tikam Pelajar di Mergangsan, https://jogja.tribunnews.com/2020/11/12/dendam-terkena-klitih-pemuda-tikam-pelajar-di-mergangsan?page=all.

${ }^{2}$ Sarwono, Sarlito W. \& Eko A. Meinarno. (2009). Psikologi Sosial. Jakarta: Penerbit Salemba Humanika.

${ }^{3}$ Ibid.
} 
of emotional bonding between parents and children as children bond more with gadgets than personal direct communication. ${ }^{4}$

\section{Influence of alcohol}

In fact, over consuming alcohol may affected brain mal function which may lead to behaviour disorder with indicators as follows:

1. Over prioritizing his/herself

2. Depending to someone/ other people

3. Over-estimated his/herself and feeling superior

Basically, under alcohol effect, someone potentially committed unconscious crime. It can be said that alcohol can drive someone to act unusually. He/she get offended easily, his/her attention toward surrounding distracted easily as alcohol pressing self-control nerve, so that someone can be more aggressive. The uncontrolled consumption linked to immoral acts or even crimes.

AKP Deni Irwansyah KASATRESKRIM Slemanregency police department emphasize that beside potentially leads to crime, alcohol also harmful to the health. Majority crime perpetrators are consuming alcohol. The considerable amount of Klithih and random street attacking are related with alcohol and drugs abuse.

According to Soeprapto, sociologist of University of Gadjah Mada, Yogyakarta, his research from 2018 to 2010 indicated that offenders of street crime in Yogyakarta were consumers of alcohol and drugs abuser. Before committing the crime, they usually consume alcohol. ${ }^{5}$

Over consumed and uncontrolled alcohol certainly will leads to certain issues whether for the consumer himself or other people around him. It also threatened the stability of local area development. In general, it may trigger people to committed crimes including Klithih.

\section{The lack of education}

Low education level of a society resulted low creativity level and low self-control which risen the number of crime in the society.In contrast, well-educated society enables crime prevention or at least enable it to be controlled. In the discussion regarding education, we shall look up to it goals namely realization of the proper and correct cultural values transformation from one generation to the next generation. The one thing author needs to emphasize is that even though the lack of education in a society allows the emerging of crimes, but it cannot be fully blame on the Klithih crime in special region of Yogyakarta.

\footnotetext{
${ }^{4}$ Muhadjir Darwin dkk, Membangun Relasi Digital Antara Orang Tua Siswa Dengan Sekolah Dalam Penanganan Tawuran Pelajar Di Yogvakarta, Jurnal Populasi Volume 25 Nomor 22017

${ }^{5}$ Suprapto, "Narkoba dan Minuman Keras Dianggap Pemicu Maraknya Klitih" daam https:/yogyakarta.kompas.com/ $\mathrm{read} / 2020 / 02 / 05 / 18205311 /$ narkoba-dan-minuman-keras-dianggap-pemicu-maraknya-klitih.
} 
Related to causing factors, author would like to add another factor beside the described above namely personal factor. It means that, even though someone interacts with negative same-age friends, it would not be affected if he/she has no inner desire to follow the negativity. In contrast, even though someone has adequate family affection and material, but if he/she owns hateful feeling, he/she a potential law breaker, due to his/her personal intention.

Hawari (1997) noted that the lack of parental role model becomes the main cause of teenager's troubled behaviour. Petterson (in Kerig dkk, 2012) kurangnya keterlibatan orang tua memiliki kontribusi masalah perilaku pada anak. According toSatrok (2014) the common hobbies and activities resulting conformity and suitability. Miron (2006) noted that one of teenager main goals is to confirm their individual identity outside family circle. Therefore, some of them seek for the confirmation from same-age friends circle. Further, Desmita (2005) mentioned that negative side of same-age circle among teenagers is that the influence to negative behaviours such as delinquency, free sex and drugs abuse. They assume that they will be noticed well by gang members or hangout buddies if they are brave enough to harm others on the street. This indicates that violence is a way of obtain acceptance and acknowledgement in a group. This belief emerged as an effect of individual conformity in a group (gang).

Baron \& Byrne (2012) formulated that conformity refers to behaviour and belief changes resulted from group pressure as it can be real of fake pressure. According to Myers (2012) someone tend to take actions that are expected by social group as the actions are conformity expression on values hold by the group. The values consist of rules of accepted and expected behaviour. In a research conducting by Wilujeng (2012) shown that conformity plays significant contribution toward aggressive behaviour in teenage gang. It can be concluded from this research that Klithih's causing factors namely revenge, environment, family relation whether with broken home or not background, alcohol, lack of education and personal character.

\section{EffortsMacro criminology efforts to eradicate Klithih in the special region of Yogyakarta}

Basically it is difficult to terminate Klithih. It is mandatory to involve law apparatus especially Yogyakarta region police department. There are two method can be taken namely penal and non-penal as police officer plays social control role that allow them to act rapidly in handling youngster crimes before it brought material and non-material harms.

\section{Non-Penal method}

Crime eradication through informal or non-penal method is more to preventive actions. There are several forms of application can be taken, namely

a. Conducting Focus Group Discussion (FGD) 
Police Department of special region of Yogyakarta held Focus Group Discussion (FGD) involving headmasters of Junior and Senior high schools across the region and education office to insert common understanding as well as supervision method to the students to prevent them committed crime. BHABINKAMTIBMAS conveyed speech and socialization for public in every sub-districts regularly. Meanwhile,SATBIMAS conveyed socialization in schools regularly.

b. conducting profiling toKlithih perpetrators

Profiling analysis of Klithih perpetrators is done by observing various aspects including biological, psychological and method in committed the crime. Klithih as a crime type is not particularly arranged in specific law as this term only known in the region of Yogyakarta. Therefore, the available data only on crimes regulated in law such as murder, persecution and burglary. In order to handle Klithih, the applied legal basis is Penal law (KUHP) and emergency law of the Republic of Indonesia number 12 of 1951.

c. Conducting regular patrol

Preventive efforts are conducted after pre-emptive efforts are done. It aims to prevent and reduce the number of crimes. Preventive efforts taken by Police Department of Special region of Yogyakarta namely night patrol conducted by special team anti-bandit of Bhayangkara unit to supervise the security of Yogyakarta area.The team is checking every teenage crowd in the street, especially at night time and dismiss them when necessary.

d. Enhance public involvement

Public can be involve in individual or group actions. Such involvement in children protection is arranged in Article 72, Paragraph (3) of children protection law which divided into eight action points. The points are description of obligations and responsibilities related to children protection through public involvement.

e. Improving family resilience

It is important to improve family resilience in the eradication of Klithih crime. Parent role in children'sup brought especially toward millennial generation is the most essential, since family is the first education source of children.Children's character and behaviour determines by early education provided by family. Therefore, family, especially parent is the most dominant factor in children's mental shaping. In Parent can also plays role as children's motivation. Parents shall motivate their children to commit good dead as well as to pursue education.

Family is the first and the most important institution in socialization and civilization process of children's personality. It constantly provides behaviour role model for the children to learn to be decent citizen. Ideally, family is a guidance institution to develop appropriate 
social character, direct children to be able to solve their adaptation issues, guide them to have motoric, verbal and social skill needed in order to adjust to the surrounding.

Such guidance is conducted in cooperation with police officer and army as well as school institutions. Actually, students with tendency to commit Klithih can be detected as they usually join a gang, comes from certain schools and so on. These students shall be coached in terms of discipline, legal knowledge, mentality and so on massively.

Other program can also support the goal such as outbound and discipline camp. Strict rules enforcement related motorcycle usage for under age students shall be done since they did not hold driving licence but still drive to school. Therefore, public transport facilities are required to minimise motorcycle usageby the students. The availability of free of charge school bus that can be provided through cooperation with independent transport service provider to commute from and to school may prevent students from using motorcycle.

It is necessary to establish local law on Klithihthe special region of Yogyakarta. Contain of this law shall cover prevention, enforcement and rehabilitation aspects of Klithih perpetrators. For example, the law regulate about limitation of students' night hours, addition to study hours, involvement of villagers to eradicate Klithih, social punishment for Klithih perpetrators as well as cooperation with stakeholders namely security officers, local government or related institutions.

\section{Penal efforts}

Eradication of Klithih crimes in repressive forms are taken after the crimes are committed. It usually involves arrest, detention, punishment and imprisonment. Aim of penalty is to fix the outlaw behaviours since they against existing norms in the society.

The act of Klithih is not only a form of social dynamic of teenage rebellion behaviour as it has gone further to be a form of crime that has penal consequences. Perpetrators can be charged under persecution violation which expressive verbis set forth in Article 351 KUHP that maximally can be sentenced for two years and eight months.

According to expressive verbis of law number 11 of 2012 concerning trial system on children, the term of "children that committed unlawful act" refers to children in the age of 12 to 18 years old. If Klithih perpetrators are teenager around that age, their trial shall be in accordance to children trial that protect certain rights as children. This meant to ensure the children safety and security. ${ }^{6}$

There is a diversion mechanism in children's trial system.Diversion means the swift of children's trial system from penal process to non-penal process. It allows case settlement to

\footnotetext{
${ }^{6}$ Undang-Undang No. 11 Tahun 2012 tentang Sistem Peradilan Anak
} 
done under deliberation as long as the penalty length is less than 7 years. Aim of diversion is to reach the most appropriate solution that is accord for both sides. Legal instrument has regulates this mechanism in order to protect children's interests and enable police officer to conduct their protector and guider roles.

Other repressive effort namely chasing and arresting the perpetrators as well as investigate them along with crime evidence. Case documents will be further send to state attorney to be processed.

\section{CONCLUSION}

Causing factors of Klithih crime including internal factors namely revenge and personal factor or encouragement from the inside to behave positively or negatively. External factors comes from surrounding due to the lack of parental supervision that allow children to involve in crime, the over-consuming and uncontrolled of alcohol that lead to social issues.

There are several efforts conducted by police department to eradicate Klithih crime that are penal and non-penal act. They constantly enhance supervision on prone areas, conducting regular patrol, inspecting alcohol sellers, encourage public to report any kind of Klithih crime, socialization in schools and handling Klithih perpetrators as regulated by the law. Future concept in eradicating this crime is strengthening family resilience through local law or governor regulation on family resilience. It also can be done through training for students that potentially committed Klithih and regulate motorcycle usage for under age children. To support this plan, local law on prevention, handling and rehabilitation toward Klithih perpetrators is needed.

To enforce law, especially toward Klithih perpetrators, the process shall be in accordance to existing law. Strict sanction also required to prevent them re-conducting the crime. It is expected that police officers and law enforcers to be fair in enforcing the regulations. Nevertheless, family holds the most crucial role in shaping children's character. Therefore, it supposed to provide sufficient guidance, religious knowledge as well as supervise children's behavior in order to be constantly positive.

It is a common responsibility of government, family and law enforcers to eradicate students gang crimes. The act taken shall be comprehensive by prioritizing children/teenager guidance. Law enforcement shall avoid traumatic effect for the children/ teenagers. The children shall be directed under certain guidance method to assist them find out their positive characters which will enables them to adjust in the society. These are the most important steps for law enforcers to handle teenage unlawful acts. 


\section{Bibliography}

\section{Books:}

Sarwono, Sarlito W. \& Eko A. Meinarno. (2009). Psikologi Sosial. Jakarta: Penerbit Salemba Humanika

\section{Journal articles:}

Dendam Terkena Klitih, Pemuda Tikam Pelajar di Mergangsan, https://jogja. tribunnews.com/2020/11/12/dendam-terkena-klitih-pemuda-tikam-pelajar-dimergangsan?page $=$ all

Muhadjir Darwin dkk, Membangun Relasi Digital Antara Orang Tua Siswa Dengan Sekolah Dalam Penanganan Tawuran Pelajar Di Yogyakarta, Jurnal Populasi Volume 25 Nomor 22017

Suprapto, "Narkoba dan Minuman Keras Dianggap Pemicu Maraknya Klitih" daam https:// yogyakarta.kompas.com/read/2020/02 /05/18205311/narkoba-dan-minuman-kerasdianggap-pemicu-maraknya-klitih.

\section{Laws and regulations:}

Indonesia, Undang-Undang Dasar Negara Republik Indonesia 1945

Indonesia, Kitab Undang-Undang Hukum Pidana

Indonesia, Undang-Undang Nomor 11 Tahun 2012 tentang Sistem Peradilan Pidana Anak

Indonesia, Undang-Undang Nomor 35 Tahun 2014 tentang Perubahan atas Undang-Undang Nomor 23 Tahun 2002 tentang Perlindungan Anak

Indonesia, Undang-Undang nomor 13 tahun 2006 tentang Perlindungan Saksi dan Korban Indonesia, Undang-Undang Nomor 2 Tahun 2002 tentang Kepolisian 